\title{
The Effect of Adjustable Outflow on the Fluctuations in the Level of Surface and Ground Water
}

\author{
Antoni Grzywna ${ }^{*}$, Alina Kowalczyk-Juśko' \\ 1 Department of Environmental Engineering and Geodesy, University of Life Sciences in Lublin, Leszczynskie- \\ go 7, 20-069 Lublin, Poland \\ * Corresponding author's e-mail: antoni.grzywna@up.lublin.pl
}

\begin{abstract}
This paper aims to analyze the variability of the surface and ground water levels in Ambona peatlands. The depth at which the ground water table occurred was studied with reference to the adopted land drainage standards. The studies were carried out in 2009/10-2015/16 for natural and regulated water outflows. The analysis of annual total precipitation suggests that in the analyzed period some years were very wet (2009/10 and 2013/14), some were wet (2010/11,2012/13 and 2015/16), one year was dry (2014/15) and one year was normal (2011/12). The 7-year average seasonal precipitation amounted to $598 \mathrm{~mm}$, which was $71 \mathrm{~mm}$ higher than the average precipitation recorded in 30 years. The level of water in the river under adjustable outflow conditions ranged from 55 to $77 \mathrm{~cm}$. The level of water under natural outflow ranged from 18 to $49 \mathrm{~cm}$. In the area with adjustable outflow, the average draining depth was $47 \mathrm{~cm}$. In the remaining area, not covered by the irrigation system, the draining depth was $64 \mathrm{~cm}$. Additionally, the dynamics of variance in the water level under natural outflow conditions was clearly higher.
\end{abstract}

Keywords: adjustable outflow, precipitation, surface water, ground water

\section{INTRODUCTION}

Water protection is comprehensively regulated by the Water Framework Directive (2000/60/EC), the main goal of which is ensuring good quality of water by 2015. In Poland, water protection takes on a special significance because it is a country with very poor water resources [Chełmicki 2002]. Water deficit imposes limitations on the possibility of economic development and necessitates a thorough analysis of risks [Mioduszewski 2012, 2014]. Polesie Lubelskie is an area with $1^{\text {st }}$ class rainwater storage needs. Availability of water in the specific amount, quality and time is an essential element of sustainable economic development [Chmielewski (ed.) 2000].

Water and natural factors determine the environment. In addition, certain adverse effects connected with water occur on the Earth. These include droughts and floods. Apart from the spatial variation in the distribution of precipitation, we also deal with its variability in particular years and seasons [Xoplaki et al. 2004; Bajkiewicz-Grabowska, Mikulski 2006; Chmielewski, Sławiński 2009].

The identification of the hydromorphological status of surface water should involve a description of changes in the outflow regime [Brandyk 2002]. Such changes are measured as the ratio of average flow under regulated conditions to average flow under natural conditions. The information on water resources includes characteristic water levels and flows in particular months.

This paper aims to analyze the variability of the levels of surface and ground water in peatlands. The depth at which the ground water table occurred was studied with reference to the adopted land drainage standards. The studies were carried out in 2009/10-2015/16 for natural and regulated water outflows. 


\section{MATERIAL AND METHODS}

Since October 1999, the Department of Environment Management and Geodesy Engineering at the University of Life Sciences in Lublin has carried out comprehensive studies of water resources in the catchment area of the Ochożanka river. The studies mainly involve: measurements of daily water levels in the closing section, monthly flow rates and periodic measurements of geometric parameters of streams. The measurements are performed both in the Ochożanka river and in drainage ditches in the peatlands.

This paper presents the results of hydrological measurements carried out in 2009/10-2015/16. The tests were performed in alder peatlands Ambona extending over an area of 181 ha in hydrometric sections (Fig. 1). Hydrological observations included:

- Measurement of surface water levels in the river and ditches,

- Measurement of the depth at which the ground water table occurred in piezometers,

- Maintenance processes.

The weather conditions in the catchment area were determined based on the data provided by the agrometeorological station in Sosnowica. Digital data recorders were used for the purpose of hydrological and meteorological measurements.

Western Polesie, according to the division of Poland into climatic zones (Romer), is located within the climatic area of the Great Valleys in the Chełm-Podlasie region. The region is characterized by high annual temperature amplitude reaching $23.5^{\circ} \mathrm{C}$ and the average total annual rainfall of $560 \mathrm{~mm}$. According to the classification of agricultural regions (Gumiński), the analyzed area is situated at the border of District IX - Eastern and District XIII - Chełm. The number of snow cover days is 80 and that of ground frost days 132. In terms of the climatic regions classification, this area is situated in the Mazovia-Podlasie region where summer starts early [Chmielewski, Sławiński 2009]. As far as climatic zones classification is concerned [Kaszewski 2008], this area is situated in Polesie Region which is characterized by very low climate variability.

\section{RESULTS}

The studies were carried out over 7 hydrological years in the Ambona peatland under variable precipitation conditions. It provided an opportunity for objective evaluation of the drainage system operation. The analysis of annual total precipitation suggests that in the analyzed period, some years were very wet (2009/10 and 2013/14), some were wet (2010/11, 2012/13 and 2015/16), one year was dry (2014/15) and one year was normal (2011/12) [Miętus et al. 2005]. The 7-year average seasonal precipitation amounted to $598 \mathrm{~mm}$ (Table 1), which was $71 \mathrm{~mm}$ higher than average precipitation recorded in 30 years [Grzywna et al. 2016b]. In the winter hydrological half-year, the highest precipitation was recorded in 2013/14 - $193 \mathrm{~mm}$, while the lowest in 2009/10 - 134 $\mathrm{mm}$. Precipitation was considerably more varied in the summer half. It ranged from $262 \mathrm{~mm}$ in $2014 / 15$ to $541 \mathrm{~mm}$ in 2009/10 (51\% higher than the multi-year average). Precipitation distribution throughout a year was uneven and it ranged from $30 \mathrm{~mm}$ in December to $96 \mathrm{~mm}$ in May, on average. In the studied period, the heaviest precipitation was recorded in July 2011 - $242 \mathrm{~mm}$, while

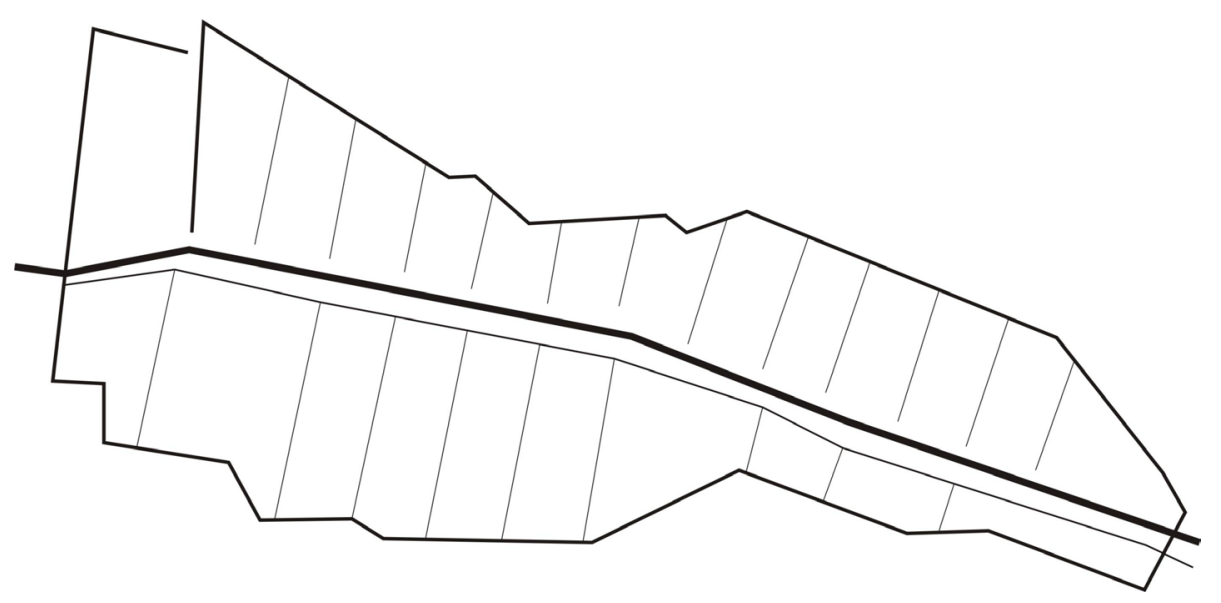

Fig. 1. Hydrographic network of the Ambona drainage facility 
Table 1. Periodic precipitation totals [mm]

\begin{tabular}{|c|c|c|c|c|c|c|}
\hline \multirow{2}{*}{ Year } & \multicolumn{2}{|c|}{ XI-IV } & \multicolumn{2}{c|}{ V-X } & \multicolumn{2}{c|}{ XI-X } \\
\cline { 2 - 6 } & $\mathrm{mm}$ & Classification & $\mathrm{mm}$ & Classification & $\mathrm{mm}$ & Classification \\
\hline $2009 / 10$ & 134 & dry & 541 & extremely wet & 675 & very wet \\
\hline $2010 / 11$ & 167 & normal & 486 & very wet & 653 & wet \\
\hline $2011 / 12$ & 148 & dry & 373 & normal & 521 & normal \\
\hline $2012 / 13$ & 189 & wet & 416 & wet & 605 & wet \\
\hline $2013 / 14$ & 193 & wet & 490 & very wet & 683 & very wet \\
\hline $2014 / 15$ & 205 & wet & 262 & very dry & 467 & dry \\
\hline $2015 / 16$ & 275 & extremely wet & 335 & normal & 610 & wet \\
\hline Average & 187 & normal & 411 & wet & 598 & wet \\
\hline $1985-2014$ & 169 & normal & 358 & normal & 527 & normal \\
\hline
\end{tabular}

the lowest amount was noted down in November 2011 and February 2015 - 2 mm (Figure 2).

The normally positive water balance in the winter season and the negative one in the summer season indicate the need for a very early storage of rainwater in the natural environment. Field studies carried out under different water supply conditions revealed very poor water resources. Therefore, a regulated outflow irrigation system had to be applied [Pokładek, Nyc 2007; Nyc, Pokładek 2011].

Thanks to all-year-round regulation of the outflows, the ground water level stopped decreasing. The operation of dams increased the stability of surface and ground water levels. Under the regulated outflow conditions the variance in surface water levels remained below $22 \mathrm{~cm}$. The coefficient of variation of mean monthly water levels was only $6 \%$. The level of water in the river ranged from 55 to $77 \mathrm{~cm}$, given the depth of 120 $\mathrm{cm}$ (Figure 3). The highest average water levels were recorded in March, whereas the lowest ones in August._The average water level of the multiyear was $70 \mathrm{~cm}$. For ground water levels, the vari- ance did not exceed $37 \mathrm{~cm}$. In the vegetation period, the average meadow draining depth within the range of the dam was $47 \mathrm{~cm}$. Land draining depth ranged from $28 \mathrm{~cm}$ at the beginning of the vegetation period to $65 \mathrm{~cm}$ at the end of that period. The acceptable maximum draining standard for the analyzed alder peatlands is $60 \mathrm{~cm}$ [Szajda 2009]. Under the regulated outflow conditions, the ground water level decreased excessively only in 2012. Although the precipitation levels in particular years were differentiated, the surface and ground water levels were successfully stabilized. Thanks to all-year-round regulation of the outflows, the ground water level stopped decreasing and the consequences of excessive dryness in the vegetation period could be prevented.

In the analogous period, at checkpoints located outside the dam impact zone, the variance in surface water levels amounted to $31 \mathrm{~cm}$. The coefficient of variation of mean monthly water levels was $13 \%$. The level of water in the river ranged from 18 to $49 \mathrm{~cm}$, given $115 \mathrm{~cm}$ depth of the river bed. The highest average water levels were recorded in March, whereas the lowest

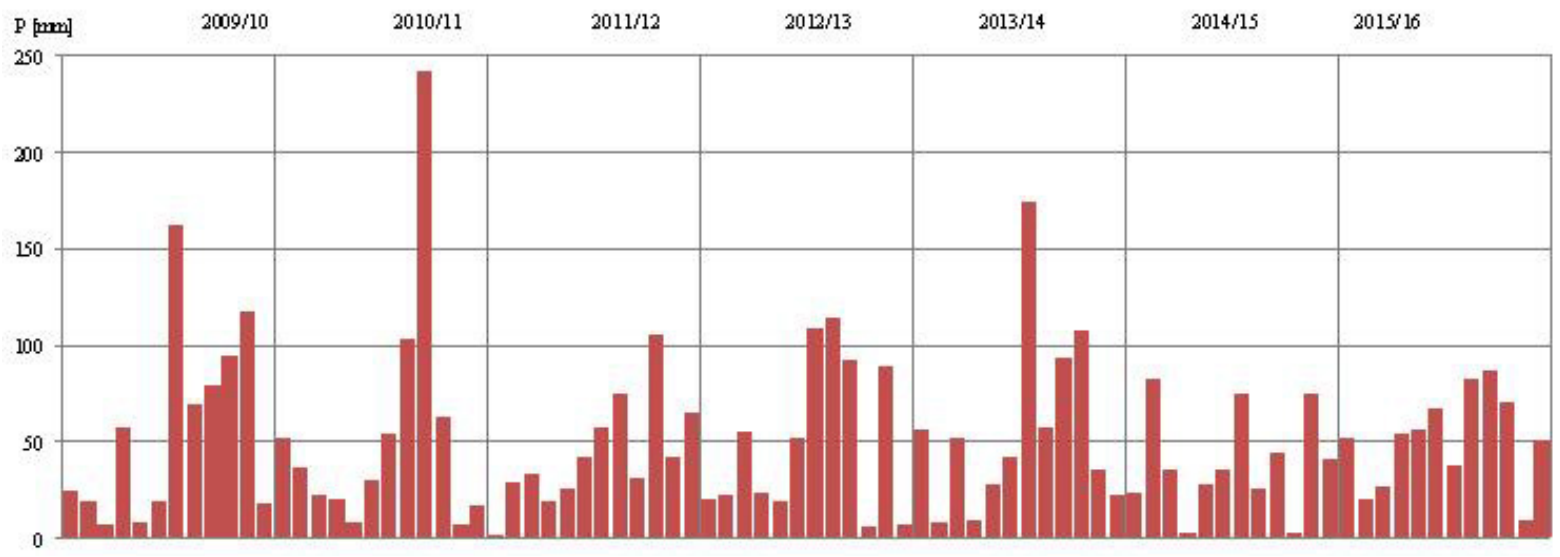

Fig. 2. Monthly rainfall in $2009 / 10$ and $2015 / 16$ years 
a)

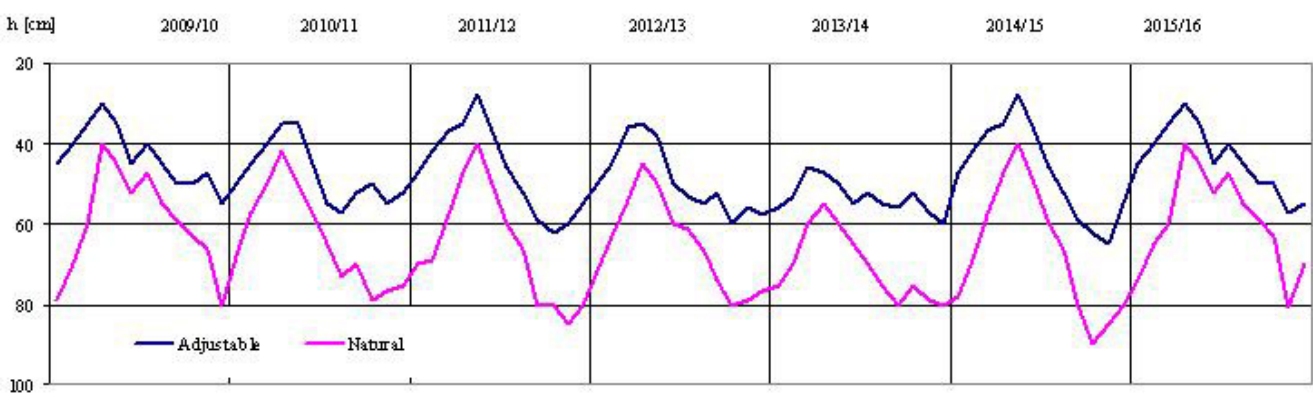

b)

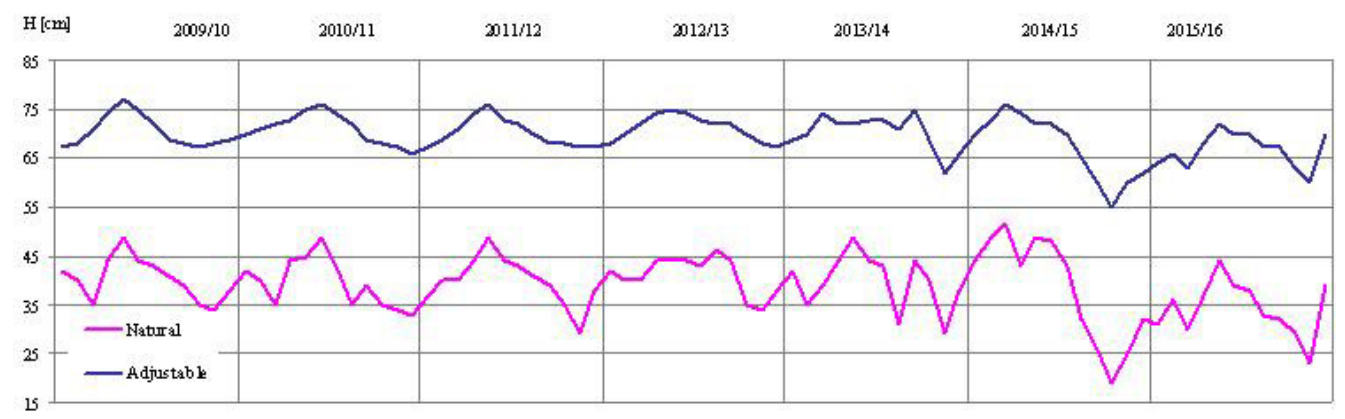

Fig. 3. Monthly average of ground water depth and surface water levels

ones in September. The average water level of the multi-year was $49 \mathrm{~cm}$ and $21 \mathrm{~cm}$ was lower than the regulated outflow. In the vegetation period, the variance in ground water levels reached 64 $\mathrm{cm}$. Land draining depth ranged from $40 \mathrm{~cm}$ in March to $90 \mathrm{~cm}$ in August 2015 (Figure 3). Under the natural outflow conditions, the ground water level decreased at the beginning of June. Similarly to the checkpoints located within the dam impact zone, the highest reduction in the level of water was recorded in 2015. In 2012 and 2013 soil drought occurred at non-irrigated checkpoints. In the remaining years, despite high total rainfall, the water level was also excessively reduced. Even in very dry vegetation periods in 2014 and 2016, a hydrological drought occurred.

Groundwater levels are also characterized by spatial variability [Kumar, Remadei 2006; Grzywna et al. 2016a; Bhadra et al. 2018]. The lowest values of depth at which the ground water level was found were normally recorded in the centre of the meadow section. The lowest level of ground water was recorded near the drainage ditch (out of the range of the dam). In dry year 2015 soil drought occurred at all checkpoints.

The dynamics of ground water levels in the analyzed Ambona peatlands was similar under the natural and regulated outflow conditions and it was mainly determined by the impact of weather conditions. The analysis of trends related to changes in surface and ground water levels in time consisted of testing the zero regression slope hypothesis [MuratBłażejewska et al. 2005]. According to the analysis, the tested hypothesis was found statistically significant in the river and in piezometric wells.

A correlation analysis was carried out in order to determine the relationship between the surface water levels in the river and ground water levels. The tests revealed a statistically significant relationship (level of significance $\alpha=0.05$ ) between the surface and ground water levels. The results indicate that the strongest relationship exists between the level of water in the river and the level of water in the centre of the meadow section $\left(\mathrm{r}^{2}=0.54\right)$. The relationship between water levels points to a strong hydraulic bond between the surface waters and shallow underground waters that are characterized by a similar dynamics of changes, mainly determined by the weather conditions.

\section{CONCLUSIONS}

1. In small agricultural catchment areas with very limited water resources, outflow should be regulated to prevent hydrological and soil drought.

2. As a result of all-year-round regulation of water in a stream, the effects of maintaining large resources of stored water were very good. The average water level of the multi-year was $39 \mathrm{~cm}$ and $31 \mathrm{~cm}$ was lower than the regulated drain. 
3. In the area with regulated outflow the average draining depth was $47 \mathrm{~cm}$. In the remaining area, not covered by the irrigation system, the draining depth was $64 \mathrm{~cm}$. Additionally, the dynamics of variance in the water level under natural outflow conditions was clearly higher.

4. The effect of an irrigation system with regulated outflow on the levels of surface and ground water depends on correct agricultural management, operating processes related to the use and maintenance of the irrigation system and the level and distribution of rainfall.

\section{REFERENCES}

1. Bhadra B.K., Paliwal R., Srinivasa Rao S. 2018. Geospatial Analysis of Recharge of Groundwater and Irrigation Draft from Different Aquifer Systems of Rajasthan, India. In: Saha D., Marwaha S., Mukherjee A. (eds) Clean and Sustainable Groundwater in India. Springer Hydrogeology, https://doi. org/10.1007/978-981-10-4552-3_16.

2. Bajkiewicz-Grabowska E., Mikulski Z. 2006. General hydrology. PWN Warszawa. (in Polish)

3. Brandyk T. 2002. Water retention status of hydrogenic habitats and its conditioning. Wiadomości Melioracyjne i Łąkarskie, 1, 18-21 (in Polish).

4. Chełmicki W. 2002. Water - resources, degradation, protection. PWN Warszawa. (in Polish)

5. Chmielewski T.J. (Ed.) 2000. Restoration of natural objects - economic and ecological aspects. UMCS Lublin (in Polish).

6. Chmielewski T.J., Sławiński C. (Ed.) 2009. Nature and landscape monitoring system in the West Polesie Region. UMCS Lublin.

7. Grzywna A., Kamińska A., Bochniak A. 2016a. Analysis of spatial variability in the depth of the water table in grassland areas. Rocznik Ochrona Środowiska, 18, 291-302.
8. Grzywna A., Czarnecki Z., Węgorek T. 2016b. Assessment of components of the water balance of drained peatbog. Rocznik Ochrona Środowiska, 18, 519-530. (in Polish)

9. Kaszewski M. 2008. Climatic conditions of the Lublin region. UMCS Lublin. (in Polish)

10. Kumar V., Remadei. 2006. Kriging of groundwater levels - a case study. Journal of Spatial Hydrology, 6 (1), 81-92.

11. Miętus M., Filipiak J., Owczarek M., Jakusik E., 2005. Variability of precipitation conditions in the area of the Polish coast of the Baltic Sea in the light of the quantitative rainfall classification. Materiały Badawcze IMGW, Meteorologia, 37. (in Polish)

12. Mioduszewski W. 2012. Small water reservoirs their function and construction. Journal of Water and Land Development, 17, 45-52.

13. Mioduszewski W. 2014. Small (natural) water retention in rural areas. Journal of Water and Land Development, 20, 19-29.

14. Murat-Błażejewska S., Kanclerz J., Sojka M. 2005. Variability states groundwater and surface waters in the catchment area of the river Mala Wełna in hydrological years 2000-2004. Zeszyty Problemowe Nauk Rolniczych, 506, 303-308.

15. Nyc K., Pokładek R. 2011. Water management in valley areas. Postępy Nauk Rolniczych, 1, 79-89 (in Polish).

16. Pokładek R., Nyc K. 2007. The possibility of water management in small agricultural catchments. Zeszyty Problemowe Nauk Rolniczych, 519, 259-268 (in Polish).

17. Szajda J. 2009. Prevention of the effects of meteorological droughts on peat-muck and peat soils. Woda-Środowisko-Obszary Wiejskie, Rozprawy naukowe i monografie, 26 (in Polish).

18. Xoplaki E., González-Rouco J.F. , Luterbacher J., Wanner H.. 2004. Wet season Mediterranean precipitation variability: influence of largescale dynamics and trends. Climate Dynamics, 23 (1), 63-78. 